\title{
Customary Law of Larwul Ngabal in the Implementation of Regional Autonomy in North Moluccas
}

\author{
Rosdalina Bukido', Nam Rumkel², Ismail Suardi Wekke ${ }^{3}$, Elin Palm \\ ${ }^{1}$ Faculty Syariah, Institut Agama Islam Negeri Manado, Indonesia. E-mail: rosdalina21@gmail.com \\ ${ }^{2}$ Faculty of Law, Khairun University, Ternate, Indonesia. E-mail: nrumkel@gmail.com \\ 3 Sekolah Tinggi Agama Islam Negeri (STAIN) Sorong, Indonesia. E-mail: iswekke@gmail.com \\ 4 Linkoping University, Sweden. E-mail: elin.palm@liu.se
}

\section{ARTICLE INFO}

Keywords:

Adat Law; Customary Law;

Larwul Ngabal; Regional

Autonomy

How to cite:

Bukido, R., Rumkel, N., Wekke, I.S., and Palm, E. (2018). “Customary Law of Larwul Ngabal in the Implementation of Regional Autonomy in North Moluccas," Hasanuddin Law Review, 4(2): 242-255

DOI:

10.20956/halrev.v4i2.1351

\section{ABSTRACT}

The Kei Islands of Southeast Moluccas, like other parts of Indonesia, have a customary order and cultural diversity. The values of local wisdom existing in the Kei community, which is contained in the customary law of Larwul Ngabal, is a very important cultural social capital in the social integration of its society. The type of study was an empirical research with sociological-anthropological juridical approach. The results show that the existence of customary law of Larwul Ngabal supports the implementation of regional autonomy with full authority and reinforcement in local regulations based on local wisdom in Kei Island. The dominant factors that caused the values of customary law of Larwul Ngabal have not provided legal strength in the implementation of local government is because it is determined by the recruitment factor of the leader who lacks capacity and competence. Added to the polarization of political parties and the values of local wisdom on financial strength in determining leadership. Therefore, to realize good local governance in Kei Islands, the values of customary law of Larwul Ngabal in various Local Regulations and local government policies must be accommodated, keeping in mind the custom, governmental and religious factors that are the foundation of Kei community life.

Copyright (C) 2018 HALREV. All rights reserved.

\section{Introduction}

The Indonesian nation contains a pluralistic society. The pluralism is characterized by ethnic, religious, linguistic, and cultural diversity. ${ }^{1}$ Historically, the plurality has existed since centuries ago and it becomes a cultural treasure that makes very proud. Such diversity can certainly give hope to the community to grow and develop in the bonds

1 Bahar, S. (ed), (1995), Risalah Sidang Badan Penyelidik Usaha Persiapan Kemerdekaan Indonesia (BPUPKI), Panitia Persiapan Kemerdekaan Indonesia (PPKI), Jakarta: Citra Lamtoro Agung Persada, p. 144. 
that relies on the traditions and cultures set in customary law as well as the norms that need to be obeyed governing the life of society, both individually and in groups.

Diversity is the natural human nature, ${ }^{2}$ diversity can't be denied and desired. Resisting diversity is the same as rejecting the reality of human life. Diversity is a social capital and a cultural asset to tighten the community life. The nature of diversity can't be made instantly, it is a process of cultural interaction and acculturation, which grows and develops naturally, which is adopted by society.

Variety of the diversity gave birth to the order of life and legal norms, both written and unwritten, as a guide to regulate the behavior of community life which is contained in the form of tradition and law. This tradition forms a legal behavior in the form of custom. Customary Law is one of the legal systems that is still recognized and applicable in Indonesia. In social life, the notion of customary law is often equated with customs. Even though, actually both have differences. In Indonesian, the word "adat (custom)" which means "habit" has the meaning of "one's behavior done in a certain way and continuously, which then followed by the society around for a long time". Whereas customary law, ${ }^{3}$ defined as an unwritten law (based on custom). Its meaning is closely related to local law in an area and it occurs (valid, exist, etc.) in one place only, evenly or locally; it is also made (produced, grown, lived, contained, etc.) in some certain places, so that in this study, customary law is understood as a local law that can be defined as living law and it grows in a certain place.

The absorption of customary law or written customary law is very important, because good law is in accordance with the needs of the community, because it has the values of local wisdom adopted and understood by the local community. Therefore, the establishment of legislation should pay attention to the value of local wisdom held by the community. It is certainly fair, especially in the area. The sense of community justice is reflected from the implementation and application of customary law. Therefore, the development of national law must be preceded by the knowledge and data collection of customary law that is alive and prevailing in the regions. In that way, we will gain insight into the various legal cultures in Indonesia. At the same time, we can know the customary laws that are still effectively enforced and in accordance with the current development, and customary law that can be applied and treated as national law.

The Kei Islands of Southeast Moluccas, like other parts of Indonesia, have a customary order and cultural diversity. A series of customs and cultures of society still serve as a bond for community between one another, in various dimensions of life. One part of the diversity of customs and cultures that is still maintained and preserved and framing its people, in the patterns of brotherly bonding relationships, is the customary law of Larwul Ngabal. Until now the customary law still exists and becomes an integral part in the life of society. It becomes a living law, which is made by the community as the values of local wisdom that is able to strengthen the relationship with each other in the bonds of kinship as well as rules or norms in resolving conflicts related to the life of the local community. 4

2 Sutanto, Y., et al. (2011), The Dancing Leader-Hening-Mengalir-Bertindak Jakarta: PT Kompas Media Nusantara, p. xxi.

3 Departemen Pendidikan Nasional, (2001), Kamus Besar Bahasa Indonesia, Jakarta: Balai Pustaka, p. 410.

4 Montagu, A., (ed). (2000), Manusia, Kebudayaan dan Lingkungan, Yogyakarta: Pustaka Pelajar, p. 45. 
The values of local wisdom existing in the Kei community, which is contained in the customary law of Larwul Ngabal, is a very important cultural social capital in the social integration of its society. It has been a culture that has been inherited since centuries ago. This wisdom is a cultural asset that teaches culture of peace, harmony, mutual cooperation, compassion, equality, and appreciation according to its functions and roles. In addition, it has historically demonstrated that this wisdom is capable of building social solidarity that transcends barriers of difference, whether in religion, ethnicity, ideology, language or class.

Diversity becomes a necessity and an important reality. The awareness of the diversity of nations and cultures has become a profound thought by the founders of this country in developing the ideas and concepts of the life of the nation and the state. The common aspiration towards an independent, united, sovereign, just and prosperous Indonesia is a common goal to form a government that protects the whole nation and the whole of Indonesian homeland; and promotes the common prosperity, the intellectual life of the nation, and participates in the implementation of world order.

Whereas in the context of local government, the values of custom law can be integrated into the making of Local Regulation made by the Regional Government with the Regional House of Representatives (DPRD) as the government law applied to the area. This integration may dispel the notion that codification and unification coexisting law known as the "charter" of national law, the tribes within Indonesian territory, is drawn into a legal perspective.

According to Bernard L. Tanya, ${ }^{5}$ national law becomes a burden in the culture of local communities. A national law abandonee the ways of organizing the previous public order that had been there for thousands of years. National laws put forward the characteristics of modern law, but it does not mean that it is better or more capable of creating order in society. Even the order built by the local people is more substantial than the order established by modern law laden which is full of procedures and formalistic things so that the attainment of order will be mechanistic like a machine, without the spirit or soul of the community.

Based on the description, the implementation of regional autonomy aims to accelerate the realization of community welfare through service improvement, empowerment and community participation. It can be realized well if there is community participation. It is therefore important to examine how the values of custom law that grow and develop in an area that is in the hands of the community, as long as it is not contradictory to the 1945 Constitution of the Republic of Indonesia, can be integrated into local regulations. It becomes the direction and formation of government policy in the enforcement of applicable national law, so that the existence of customary law can support the implementation of regional autonomy that has been empirically tested in solving various problems that happened, whether it is legal, political, economic.

Based on the above description, the subject matter that will be studied is How is the position of customary law of Larwul Ngabal in the policy of regional autonomy in the Kei Islands of Southeast Moluccas? How far are the customary law values of Larwul Ngabal integrated in the implementation of regional autonomy in the Kei Islands of Southeast Moluccas? What factors play a role in strengthening the customary law of Larwul Ngabal in the implementation of regional autonomy in the Kei Islands of Southeast Moluccas?

5 Tanya, B.L. (2006). Hukum Dalam Ruang Sosial. Srikandi, Edisi Maret, p. 38. 


\section{Method}

This research is conducted in Moluccas Province as population and it takes sample in 1 (one) regency that is Southeast Moluccas with capital of Langgur City and 1 (one) city that is Kota Tual whose capital is Tual. Basic consideration of the location by choosing the two areas because they are territories in Kei Islands that have imposed the customary law of Larwul Ngabal, as the legal consensus of the establishment of the alliance or community group Lorsiuw or Ursiuw (nine) and Lorlim or Urlim (five). Both regions are historically located in one region of the Kei Islands of Southeast Moluccas.

This study will examine and elevate the existence of customary law of Larwul Ngabal in Supporting the Implementation of Regional Autonomy in the Kei Islands of Southeast Moluccas as the subject of research, so this research belongs to the type of research of empirical law or commonly called Non-Doctrinal Legal Research. This study uses sociological-anthropological juridical approach.

In connection with what is described above, this research is descriptive analysis. The population of this study is the overall component of the community residing in the Kei Islands of Southeast Moluccas. The sampling of this study is based on the population selected as the study site. In this study, researchers used purposive sampling technique in determining samples with certain considerations. To get data according to variable in this research, researchers used instrument of data collecting that are interview with respondent and observation.

As an empirical research with sociological-anthropological juridical approach, the technique of data analysis is descriptive analysis. This analysis focuses on actual presentday issues, the data are then collected, compiled, described and analyzed. ${ }^{6}$

\section{Basic Concepts of the Customary Law}

Satjipto Rahardjo ${ }^{7}$ says that, "law is a matter of man and not merely a matter of regulation, and law exists for humans, not vice versa. Law should flow." The same thing was stated by Eugen Ehrlich in Bernard L. Tanya, ${ }^{8}$ who says that law is not an intellectual concept but is the reality of the relationship between man himself, the law is the relationship between humans. Humans are central in placing the function of law in society. It means that law is only a means and not a goal. Therefore, legal differences are commonplace in a society.

The author begins a legal view by basing the opinion of Rahardjo that it is wrong that there is only own way of punishment in this world. The nations of this world choose their own way of punishment, though there are some who call themselves law states, but there is no uniform way of punishment. The difference in punishment is not in the sense that one nation is more advanced than the other, but rather a distinction arising from the inequality of understanding of the law.

Rahardjo argues that modern law applied in Indonesia has an archetype originating in European law, the law in the post-independence era nevertheless proves that the length of the process of applying the colonial law has succeeded in instilling European models of law and institutions in the country. The preservation of this institution is due to the

\footnotetext{
Astuti, M.S. (1997), Pemidanaan Terhadap Anak Sebagai Pelaku Tindak Pidana, Malang: IKIP, p. 96. Raharjo, S. (2008), Biarkan Hukum Mengalir, Harian Kompas Tahun, p. 20.

Tanya, B.L. et al., (2007), Teori Hukum, Surabaya: CV Kita, p. 164-165.
} 
concern of the local political elite of a legal vacuum if the laws derived from colonial traditions are quickly abolished.

The modernity of this law has its own characteristics: ${ }^{9}$ First, it has a written form. Second, the law applies to all regions of the country. Satjipto Rahardjo quotes Marc Galanter that the current law consists of uniform rules and is applied without recognizing variations. The regulation is more territorial than "private". This means that the same rules apply to all members of the community of all tribes of religion, class, and sex. If it is recognized that there are differences, it is not something that is caused by intrinsic quality, but it is caused by the function, condition, and the results of the work that one gets in the life of this world. Third, law is an instrument used consciously to realize the political decisions of its people.

Customary law is defined as an unwritten law (based on custom). Its meaning is closely related to the meaning of local law in an area where it occurs (in effect, exist, etc.) in one place only, unevenly or locally; made (produced, grown, alive, contained, etc.) in certain places. So, in this study the customary law is also interpreted as a local law that can be interpreted as a living law and it grows in a certain place. It is related to Malinowski's view that the law is not solely in the organized society of a state, but the law as a means of social order is present in every society.

\section{Authority of the Regional Government}

\subsection{Regional Autonomy and Indigenous People}

The concept of thinking about regional autonomy contains the meaning of the existence of autonomy to the implementation of local government, ${ }^{10}$ Whereas the principle of regional autonomy by using the principle of autonomy as broadly as possible means that regions are given the authority to make local policies to provide services to increase the role of initiatives and community empowerment aimed at improving people's welfare. In addition, the principle of regional autonomy also uses the principle of autonomy that is real and responsible.

Regional autonomy which is defined as the authority of the autonomous regions to regulate and manage the interests of local communities according to their own initiative based on the aspirations of the people in accordance with the legislation ${ }^{11}$ is actually expected to prosper the local people. Increasing public welfare is the main foothold in determining the policy strategy in regional development, the meaning of welfare is related to the livelihood of many people covering some dimensions, ${ }^{12}$ such as: political field, social field, education, health, religion field.

In accordance with Article 18 of the 1945 Constitution of the Republic of Indonesia, a juridical consequence of regional government (regional division) in Indonesia on the basis of decentralization is the birth of autonomous regions which have regional autonomy in carrying out their own government affairs. In accordance with the mandate

9 Rahardjo, S. (1975), Pengertian Hukum Adat, Hukum Yang Hidup Dalam Masyarakat (living law) Dalam Hukum Nasional", (Paper). Seminar Hukum Adat dan Pembinaan Hukum Nasional, Bandung: Binacipta, p. 18.

10 Sunarno, S. (2008), Hukum Pemerintahan Daerah di Indonesia, Jakarta: Sinar Grafika, p. 8.

11 Solihin, D. (2001), Kamus Istilah Otonomi Daerah, Jakarta: Lembaga Pemberdayaan Ekonomi Kerakyatan, p. 67.

12 Ibid, p. 10. 
of the Constitution, the regional government shall administer the governmental affairs which are its authority except that the government affairs.

\subsection{Local Government and Customary Governments}

The first and foremost approach to classical and first-class political discourse is a common approach through an understanding of political science which has given rise to an understanding of government and all the phenomena that arise through its branches of scholarship. From the legal aspect, the symptom of government is approached through the science of constitutional law, state science, or the science of state administration. This perspective the government's understanding in the early stages is only understood as a dominant feature of so-called state or state.

In carrying out local government, local government is tasked based on the principle of autonomy and duty of assistance, where in the implementation, there are rights and obligations of local government organizer which is also a guideline that must be executed by every local government organizer (Local Government and DPRD). The rights of local government organizers in carrying out regional autonomy according to Law No. 32 of 2004 include matters, namely: Organizing and managing their own government affairs, selecting regional leaders, managing regional apparatus, managing local wealth, collecting taxes and levies, getting profit sharing from the management of natural resources and other resources located in the region, obtaining other rights regulated in legislation.

In the Kei Islands of Southeastern Moluccas, the government not only runs the government formally, but also runs customary government, especially in rural or village areas with high customary government structures in the hands of a "Raja (King)" under him is "Patih", then "Orang Kaya", then "Kepala Soa", and "Saniri", of each Rahanyam. Communities in the Kei Islands also have the greatest alliance of what is called the Lor or Ur community encountered in two groups: Lorlim or Urlim as a fellowship of five and Lorsiuw or Ursiuw is a nine-alliance. Lor or Ur means fellowship or group. Lim means five and Siuw means nine. So Lorlim is an alliance of five countries (Ohoi-village or desa) and Ursiuw is a nine-country alliance (Ohoi- village or desa). This kind of community fellowship can also be found in the Central Moluccas of what is known as Ulilima and Ulisiwa. While in the Ambon and Lease Islands, it is called Patalima and Patasiwa.

In order for the government organization to run well, there is a composition of legal alliance, whether it is Ursiuw or Lorlim in Kei Islands, they are called by customary government with traditional titles, ${ }^{13}$ such as: Uwel-welAi Rang-rang, the highest body in the structure of customary government, Raja (Rat) or also called the Head of Ratschap, OrangKai or also called Village Head, the Head of government in an area of Ohoi, Kepala Soa, the government official in a dusun (village), who heads several fam, Kepala Fam (Marga (Clan), the assistant of Kepala Dusun. Number of Kepala Fam in a dusun is in accordance with the number of matarumah / relatives that exist. Requirements of Kepala Fam is a person who is deemed worthy by relatives in question, Badan Saniri is a body that is accompanied by OrangKai and Kepala Soa, Marinyo, as interpreter or delivery of news. The governments at the level of Raja, OrangKai and Kepala Soa, each have Marinyo, In order for all decisions generated by these institutions known by the people who are in Ohoi or village. The village government also knows several auxiliary officials. The

13 J.A. Pattikayhatu et al., (1998), Sejarah Pemerintahan Adat di Kepulauan Kei Maluku Tenggara Ambon: Lembaga Kebudayaan Daerah Maluku, p. 30. 
tasks associated with the spiritual / religious affairs are led by certain officials: Leb Mudin, Hatib, for Islam and TU, Angam, for Catholics and Protestants.

The structure of customary government in the Kei Islands has actually been established long before the arrival of Dutch colonization in the Kei Islands, and it is maintained and recognized by the people up to now. During colonial rule, the above-mentioned government structures are only verbally affirmed by a written decision to the officials and their instruments. Likewise, with the affirmation of the offices terms as the term of the Raja and Orang Kaya, this position is according to the custom called Hilaai, which means "Great" that is a respected, honored, and appreciated person. ${ }^{14}$

\section{The Concept of Larwul and Ngabal}

\subsection{Larwul Ngabal}

Customary law Larwul Ngabal has been being adopted by people or tribe of Kei (evav) since ancient times until now. In general, most of the population in Kei Islands call it Lar = blood, some call it the layar (screen), $\mathrm{Vul}=$ red, which means red blood while Nga = spear, and Bal = Bali, means spear from Bali. Thus, Larwul Ngabal means a red-blooded spear from Bali. ${ }^{15}$ This customary law is inherited from generation to generation orally, so there are some differences in pronunciation, words or interpretation. Generally, the population of Kei Islands call it Larwul (red blood) and Ngabal (Balinese spear). Some also call it not Larwul (red blood), but Laarwul (red screen). The last interpretation refers to sailboat screens that are tapered at the top like a spear called Ngabal (a pointed pole like a Balinese spear). The meaning indicates that customary law of Larwul Ngabal, like customary law found in other regions in Indonesia, contains elements that are rules and restrictions. Although not in written form, the community hold and believe the truth and it serves as a benchmark in organizing all activities in community life.

Ter Haar classifies the customary law of Larwul Ngabal in a classification covering all customary law in Ambon and South Moluccas (Seram, Banda, Aru and Tanimbar) although it recognizes that Kei's customary law lies between the influence of Papua and the Timor Islands. ${ }^{16}$ In fact, as we see later, Customary Law of Larwul Ngabal is associated with a historical figure of Kei, who is said to have originated from Bali. In tracing the customary law of Larwul Ngabal, with historical approach, the writer has difficulty because there is no inscription or literature concerning this law, because it is inherited verbally and only strengthened by "remnants" of obedience and its implementation by Kei society from time to time.

Although there is no certainty about the dictum of its formation, all traditions connect the formation of customary law of Larwul Ngabal with Dit Sakmas, a historical figure of Kei whose ancestors were from Bali. In the 14th century, the kingdom of Majapahit expanded its power under Gajah Mada. Thus, Moluccas including Kei was also considered as the territory of the kingdom of Majapahit. In 1478 the famous kingdom collapsed, when the king of Kediri Giridradardhana seized power. It was then that the Majapahit kingdom was in turmoil and its people were scattered. In this context there was a movement of people, from Bali to Kei in the 15th century. ${ }^{17}$

14 Ibid, p. 35

15 Rahail, J.P., (1993), Larwul Ngabal:Hukum Adat Kei Bertahan Menghadapi Arus Perubahan, Jakarta: Yayasan Sejati, p. 12.

16 Ter Har, B. (1962), Adat Law di Indonesia Jakarta: Bharata, p. 5.

17 Ph. Renyaan, (1981), Kursus Adat Istiadat Evav. Langgur, p. 2. 
At that time, there was the Halaai family (Petua, leader, head) named Kasdew with his wife Dit Rangil. They entered Sorbay Bay on the west coast of Kei Kecil, and finally stopped at Letvuan village shore now. With the approval of the natives, they established a village on a rather high hill, named Ohoivuur (meaning hilltop village). Against the natives, they proclaimed themselves as representatives of the gods who came from the island of the Gods. 18 Therefore all offerings to God must pass through the Kasdew, which has three children, namely Tabtut, Fadirsamai, and Atman.

As time goes by, Kasdew returned to Bali for some time. Then he went back to Kei with another row, Jangra accompanied by his son named Dit Somar. On the way to Kei, the boat they were traveling in, was hit by a hurricane, so they were drifted into the middle of the sea. As a result, the entourage of Kasdev and Jangra parted ways. The Jangra boat sailed to the south of the Kei Islands and entered the Nerong Strait and landed in Ler Ohoilim (Kei Besar). Jangra boat contained thirty spears from Bali. While the boat boarded by Kasdev, bringing kelewang (afferak), sailing in the west Kei Kecil, could return safely to Ohoiwur.

\subsection{Larwul and Ngabal Law Unification}

There is a custom of the Hilaay (Customary stakeholders) i.e. visiting each other almost every day throughout the Kei Islands. For example, Hilaay in Elaar namely Fuutrub Renoat with Hilaay Arnuhu in Danar. At one time they met at the end of Danar-Sare Village, drinking Tuak-Arak. Arnuhu Danar offers an activity to Fuutrub Renooat to create an activity involving many people, to discuss or regulate the life of mankind with a single customary law. Fuurtrub agreed with the plan. So Hilaay agreed both to do these activities.

To realize the wishes of both Hilaay (Fuutrub and Arnuhu), then provided a buffalo, which was brought by Ditsakmas descendants of Tebtut from Letvuan. Subsequently Hilaay (Customary stakeholders) Fuutrub drew up an activity plan by inviting the Hilaays around, especially the Hilaay from Utan Lor Lim to Seram-Goram, Dob-Yar (Dobo). The buffalo was brought to the middle of Danar-Elaar. On the appointed day the Hilaay gathered somewhere, called Amalor Siran Siryen, between the villages of Elaar Lamagorang and Elaar Ngursoin. The trial then began, which was marked by the slaughter of Buffalo Siuw by La Hol Ohoiren (Lalay Wohor) from Ohoiren Ngursoin, using the Fuarter Siruk / Sirip Kifarat. After being slaughtered and cut, then distributed to the present or absent Hilaay. After the buffalo distribution event, Fuutrub Renoat Hilaay announced the enactment of the customary law of Larwul Ngabal. This event is the formulation of the customary law of Larwul and the customary law of Ngabal into a complete custom law, intact and applicable to the community, both in Ur Siuw and Lor Lim, hereinafter referred to as the customary law of Larwul Ngabal.

Based on the description, the presence of customary law of Larwul Ngabal is interpreted as: First, the formed partnership is responsible for the condition of security and order of the irregular society (chaos); Second, the "blood" in that connection has always been a symbol, that how the order of life is built on sacrifice for the achievement of social harmony in the society; and Third, there is a Balinese influence of the two fellowship formed. However, in relation to this third conclusion, it appears that the influence did not develop or affect the socio-cultural space of the community. Bali is often synonymous with Hindu religion and culture, factually very little influence in the Kei

$18 \quad$ Ibid, p. 3. 
society. However, even so, at least that fact confirmed the cultural links between the people of Kei and Bali that occurred in the past.

\section{How Far the Values of Customary Law Larwul Ngabal are integrated in the Implementation?}

Regional autonomy gives space to local governments to manage their communities, by holding to the legal values that grow and develop in society as long as it does not conflict with Pancasila and the 1945 Constitution of RI. Based on the author's observation, the customary law system of Larwul Ngabal owned by the community of islands Kei has not gained enough room to develop. Even the independence of customary regulations is depressed and will eventually be eliminated. Nevertheless, the customary law of Larwul Ngabal persists in the face of the changes and developments of an age that exist today and is a living law in society.

Theoretically, speaking of regional autonomy is also questioning about authority at the same time. Such authority is substantial in the concept of constitutionality. Autonomy is one of the principles of state governance. The government of a country encompasses all state-control activities and the exercise of the common good to achieve its objectives. In the concept of a classical legal state, the state is merely maintaining security, then in the modern era it is known as the welfare of the state that now aims to organize the security and welfare of the people. To realize the country's goal, the government organizes government within a country.

Departing from the concept of regional autonomy in which the authority to organize and manage is the substance of the autonomous region held conceptually by the local government, it integrates the values of a living law which is held and believed by the community, as long as it is not contradictory to the 1945 Constitution and fulfill four juridical requirements (1) as long as it is alive, (2) according to the development of society, (3) in accordance with the principle of NKRI, (4) regulated in law, becomes a necessity in the implementation of regional autonomy, including the introduction of customary law of Larwul Ngabal in the Kei Islands of Southeast Moluccas up to the present and in the future, which still animates the basic values of the 1945 Constitution of the Republic of Indonesia, because of the values contained in the customary law of Larwul Ngabal which is the fundamental and philosophical embraced and held by the people of Kei is a philosophy Manut Ain mehe ni Tilur, fuut Ain mehe Ngifun (all Kei people are from one descendant).

The customary law of Larwul Ngabal appears to have been clearly internalized in the rules of life of the Kei Islands community. This can be proved by the customary law of Larwul Ngabal for the people of Kei which is the supreme law which contains the invitation to the Kei community to obey, uphold and maintain the values of its sacredness in governing life, organizing the moral rights and justice either implied or explicit, because in the customary law there are basic values that are made as a reference that binds the entire community of Kei Islands from generation to generation.

The basic values set forth in the Customary Law of Larwul Ngabal consist of 7 (seven) articles. There are also 7 (Articles) which are prohibitions that should not be made and according to the level of violation is called "Sasa Sorfit" (seven layers/ban) either on Nevnev, Hanilit, Hawwar Balwarin law. ${ }^{19}$ The seven chapters in question are divided

19 Rahail, J.P. (1993). Larwul Ngabal: Hukum Adat Kei Bertahan Menghadapi Arus Perubahan. Jakarta: Yayasan Sejati, p. 13 
into: Nevnev's Law of human life and consists of 4 (four) articles (Article 1, 2, 3, 4);20 Hanilit Law Namely Regulates About Decency / Moral and Consists of 2 (Two) Articles Namely (Articles 5 and 6); The Law of Hawwar Baiwarin That Is Regulating About The Right And The Social Justice Which Is Consisted Of An Article That Is Article 7.21

The integration of customary law values of Larwul Ngabal which is still believed by the community can be done in writing in the form of laws or regulations (local regulations) applied in the area, in accordance with the present and future situation and condition, is not something impossible and not contradicting with existing written law such as Pancasila and the 1945 Constitution as well as the prevailing positive laws. The condition is motivated because customary law has a function, as a means of coercion, in addition to other functions as a game rule in social interaction. As a means of coercion, it will make citizens of fellowship obedient or obedient to the law, for fear of getting negative sanctions. Whereas as a rule of the game in social interaction, it aims to maintain good relationships between citizens of the alliance with the ruler and between citizens of fellowship with each other, in addition to ensuring the interests of the community of their own fellowship, as according to the values adopted in the fellowship.

The customary law of Larwul Ngabal is a law incarnated from the soul of the people (volkgeist), i.e. the law is not created, but grows and develops with the community, which recognizes plurality and has historical and comparative reviews. Hence, in the study of customary law, used a number of different categories, but are interrelated. The category revolves around the structure of norms or rules, legal processes, and legal culture. In terms of norm structure, the law can be interpreted with the conception of behavior as a product of compliance with normative provisions that have been standard, but it becomes a living law as stated in the customary law dictum Larwul Ngabal. While in terms of legal conception, the law can be interpreted as a social control, it can maintain order effectively, and while in terms of legal awareness, the law can be interpreted as public awareness. From that approach, the local wisdom of the people in the Kei Islands in the form of customary rules that give birth to customary institutions will be a protector for the people to be obeyed and respected.

\section{Factors Affecting Customary Law Enforcement Larwul Ngabal in Kei Island, Southeastern Moluccas}

The people of Kei Island, as indigenous peoples, have informal leaders recognized by the community, as the dominant factor in managing and expediting the activities of community life, as they gain strong support from the community. This shows that people in the Kei Islands, in addition to having informal leadership, also recognize and respect formal leadership, which is a form of recognition as an Indonesian society. Formal leadership for Kei society is not only a symbol of the state that must be obeyed and respected, but is seen as a driving force for development in various fields of life in the order of nation and state.

To realize the hopes that become the social capital of Kei society, the arrangement is in cultural concept, Custom, Government, and Religion must unite, without overthrowing each other because they have interrelationship with one another and become factors that play a role in strengthening the customary law of Larwul Ngabal in implementation of

20 Difinubun, A., et al., (2008), Tim Penyusun Hukum Adat Larwul Ngabal, Pemerintah Daerah Kabupaten Maluku Tenggara, p. 14.

21 Ibid, p. 15 
regional autonomy in the Kei Islands of Southeastern Moluccas, with reinforcement on aspects that play a role in customary law of Larwul Ngabal.

\subsection{Customary Factors}

For people in the Kei Islands, customs one of the important factors that play a role in strengthening the customary law of Larwul Ngabal. The meaning of the word "adat (custom)" is very meaningful because the birth of customary law is inherited from custom and must be maintained. For the Kei people, the word "adat (custom)" can be interpreted in three senses:22 "courtesy," in other words, adat can mean "respectful" and "good manners". Not virtuous and indiscriminate acts are called "Not well behaved" or "barbaric"; "rules", "conditions" or "ways" aimed at organizing human life into peace and happiness together. It is in this sense that "adat" is often combined with the word "istiadat" meaning the various ordinances governing human life; "Innate traits" that exist in a person. "Adat" is often equated with "habits"that are more or less gaze on people. A person who makes a mistake is usually called a "not knowing adat (custom)" person.

\subsection{Government Factor}

In Southeast Moluccas District, there are customary law community units, under the name "Ratshap" and "Ohoi," which are governed by local customary law, customary law of Larwul Ngabal. The unity of the community and its governmental tools have long existed, lived and continued to grow and maintained in the social order of society.

Since the enactment of Law Number 32 of 2004, Government Regulation No. 72 of 2005, and Regional Regulation of Moluccas Province No. 14 of 2005, the units of customary law and customary governance unit in Southeast Moluccas Regency are expected to obtain legal legality through regulation policy in field of local legislation with various adjustments based on positive legal provisions that can help smooth the implementation of local government.

\subsection{Religious Factor}

Prior to the arrival of Islam and Catholicism and Protestantism, the Moluccans had primitive beliefs. When living in a modern way, they have animistic beliefs. The belief is closely related to hunting work by using simple tools such as stone or wooden sliver. If the device succeeds in killing their prey, then it is considered that the stone or wood has a certain strength, has something that is not found in stone or other wood. When they have settled in safe / hena, moli, and Ohoi, they believe in the animism that the spirit still controls the lives of the living human beings. This belief is still embraced by some people of Moluccas up to now.

In 1606, the Kei Islands were visited by one of the Company's ships, Duifje under Willem Jansz, and relations with its inhabitants intertwined. ${ }^{23}$ In 1645, the Company entered into an agreement with the chiefs of customs of Kei that some 20 years later renewed where they claimed to be the subjects of the Company. It is known that the Company's voyages repeatedly reached the Kei archipelago to destroy the nutmeg tree that grew there. The Kei Islands were under Banda. The first attempt to spread Christianity in 1635 failed. Though on the part of the population there was a desire for education and the ability to enter Christianity repeatedly expressed, in the 18th century, this desire was not

22 Rahail, J.P. Op.Cit., p. 8

23 Asba, A.R., et al., (2012), Sejarah Kota Tual, Makassar: Pustaka Pena Press, p. 251. 
answered. Meanwhile the Muslims spread their religion and resulted in the visit of Resident Baron van Hoevell in 1887, a third of the population interpreted to number 20 thousand inhabitants have converted to Islam.

In the opinion of high officials, the spread of Christianity is desirable and only Catholic missions can act to combat Islamic propaganda. This view is accepted; in Langgur in Kei Kecil there is a Catholic mission from the Sacred Heart congregation of Isoudun. Also the Protestant party finally tried to do so. In 1900 in Ambon, an evangelism in Kei began with native labor. Both in the Kei Besar and Kei Kecil, the Christian populations of unbelievers have been successful. The number of religious schools in 1915 reached 12 in Kei Kecil and 7 in Kei Besar, all except two in the Kei Besar subsidized by the state. The subsidy was given to the nursing school in Langgur in 1913, where indigenous girls were provided with household education. ${ }^{24}$

Muslim societies in the Kei Islands as in Kota Tual formed through a process that began with the arrival of Muslims, followed by acceptance of Islam by indigenous peoples, and finally accepted Islam in the structure of society. Given its position as a spice-producing region, in this case, in general, Moluccas began to be visited by Muslim merchants. In the context of that relationship, Ternate appears to be more prominent in the historical realm of the Moluccas region, as well as Tidore. Ternate's relationship with the outside world has long been going on through clove trade. But because it does not have a commercial fleet, Ternate is a trading port that is visited by outside traders. Perhaps since the 7th century Javanese and Malay traders had been to Ternate.

With Ternate's position as a major trading port in the archipelago and the role of Arabs in commerce and sailing in the region, it is reasonable to assume that Arabic Muslims were the first to occupy Ternate. From an oral history source told about the arrival of four ulama from Iraq, each was a Mansur shaykh that broadcast Islam in Ternate and Halmahera Utara (western Halmahera coast facing the ternate), Shaykh Ya'kub who was accused in Tidore and Makean, Shaykh Amin and Shaykh Umar who broadcast Islam in behind Halmahera (East Halmahera's coastal areas). In the collective memory of the people of Ternate, the four shaykhs were the first Arabs to be in Ternate. As the oral history in general, the arrival of the four Islamic preachers is unknown. ${ }^{25}$

With the formation of the sultanate means Islam as a political culture has entered the political structure of the people of Moluccas, while the Islamic culture that regulates other economic and social life is applied gradually. Since the end of the XV century throughout the four sultanates of North Moluccas, Muslim communities have been formed, although they are still formalistic. This type of Islamism is common because the conference to Islam is through top down, the Sultan's decree to his people. When accepting Islam as a religion, they have not understood the teachings of Islam so it has not been lived and practiced.

Based on the observations of researchers in the field, there is an integration between religious values in customary law Larwul Ngabal as the local nuances in the diversity tradition of people in the Kei Islands. The combination is a fact that has been built since the presence of customary law of Larwul Ngabal and the religion adopted by the community. It is inevitable in the practice of their lives. As an implication of the process

$24 \quad$ Ibid., p. 252

25 Putuhena, M.S, (2006), 13 Abad Eksistensi Islam di Bumi Nusantara-Interaksi Islam dan Budaya di Maluku (Perspektif Historis dan Religio-Politik), Jakarta Yayasan Festival istiqlal-Mizan Khazana Ilmu-Ilmu Islam, p. 345 . 
of integration, then most of society can't distinguish firmly between the values of customary law of Larwul Ngabal with religious values which is interpreted universally.

\section{Conclusion}

The existence of customary law of Larwul Ngabal supports the implementation of regional autonomy with full authority and reinforcement in local regulations based on local wisdom in Kei Island. This is caused by the formation of local regulations and regional policies that are still dominated by various interests, both legal, political, economic and governmental interests of superiors in which the provincial-level regulation is approved by the Minister of Home Affairs while the regional regulation authorized by the Governor. Thus, the substance as a regional law has not been optimized in various local government policies for the creation of a safe, just and prosperous society.

The customary law values of Larwul Ngabal contained in 7 (seven) articles are classified into three groups: First, Nevnev's laws (Chapters 1, 2, 3, and 4) whose emphasis is on human life; Second, Hanlilian law (Articles 5 and 6) whose emphasis is on moral / moral matters; Third, the law of Hawear Balwirin (Article 7), regulates rights and social justice, as living law for the people of Kei. These values can't yet become an adhesive for people's lives because their values have not been formally integrated into local laws and local government policies.

The dominant factors that caused the values of customary law of Larwul Ngabal have not provided legal strength in the implementation of local government is because it is determined by the recruitment factor of the leader who lacks capacity and competence. Added to the polarization of political parties and the values of local wisdom on financial strength in determining leadership. Therefore, to realize good local governance in Kei Islands, the values of customary law of Larwul Ngabal in various Local Regulations and local government policies must be accommodated, keeping in mind the custom, governmental and religious factors that are the foundation of Kei community life.

\section{Acknowledgments}

Recognize those who helped in the research, especially funding supporter of your research. Include individuals who have assisted you in your study: Advisors, Financial supporters, or may other supporter i.e. Proof-readers, Typists, and Suppliers who may have given materials.

\section{References}

Asba, A.R., et al., (2012), Sejarah Kota Tual, Makassar: Pustaka Pena Press.

Astuti, M.S. (1997), Pemidanaan Terhadap Anak Sebagai Pelaku Tindak Pidana, Malang: IKIP.

Bahar, S. (ed), (1995), Risalah Sidang Badan Penyelidik Usaha Persiapan Kemerdekaan Indonesia (BPUPKI), Panitia Persiapan Kemerdekaan Indonesia (PPKI), Jakarta: Citra Lamtoro Agung Persada.

Departemen Pendidikan Nasional, (2001), Kamus Besar Bahasa Indonesia, Jakarta: Balai Pustaka. 
Difinubun, A., et al., (2008), Tim Penyusun Hukum Adat Larwul Ngabal, Pemerintah Daerah Kabupaten Maluku Tenggara.

J.A. Pattikayhatu et al., (1998), Sejarah Pemerintahan Adat di Kepulauan Kei Maluku Tenggara Ambon: Lembaga Kebudayaan Daerah Maluku.

Montagu, A., (ed). (2000), Manusia, Kebudayaan dan Lingkungan, Yogyakarta: Pustaka Pelajar.

Ph. Renyaan, (1981), Kursus Adat Istiadat Evav. Langgur.

Putuhena, M.S, (2006), 13 Abad Eksistensi Islam di Bumi Nusantara-Interaksi Islam dan Budaya di Maluku (Perspektif Historis dan Religio-Politik). Jakarta: Yayasan Festival istiqlal-Mizan Khazana Ilmu-Ilmu Islam.

Rahail, J.P. (1993). Larwul Ngabal: Hukum Adat Kei Bertahan Menghadapi Arus Perubahan. Jakarta: Yayasan Sejati.

Rahardjo, S. (1975), Pengertian Hukum Adat, Hukum Yang Hidup Dalam Masyarakat (living law) Dalam Hukum Nasional", (Paper). Seminar Hukum Adat dan Pembinaan Hukum Nasional, Bandung: Binacipta.

Solihin, D. (2001), Kamus Istilah Otonomi Daerah, Jakarta: Lembaga Pemberdayaan Ekonomi Kerakyatan.

Sunarno, S. (2008), Hukum Pemerintahan Daerah di Indonesia, Jakarta: Sinar Grafika.

Sutanto, Y., et al. (2011), The Dancing Leader-Hening-Mengalir-Bertindak Jakarta: PT Kompas Media Nusantara.

Tanya, B.L. (2006). Hukum Dalam Ruang Sosial. Srikandi, Edisi Maret.

Tanya, B.L. et al., (2007), Teori Hukum, Surabaya: CV Kita.

Ter Har, B. (1962). Adat Law di Indonesia Jakarta: Bharata. 